Volume 2, Nomor 2, Desember 2021, 125-140

e-ISSN: 2776-4532 | p-ISSN: 2798-0073

DOl: 10.53491/porosonim.v2i2.122

http://e-journal.iainfmpapua.ac.id/index.php/porosonim

ININNAWA

\title{
(Pendidikan Karakter Pada Anak Dalam Tradisi Suku Bugis Di Kampung Kukup Koya Koso Kota Jayapura)
}

\author{
Andika Dian Saputra ${ }^{[1]}$, Abd. Karman ${ }^{[2]}$, M. Syukri Nawir ${ }^{[3]}$ \\ $[1,2,3]$ IAIN Fattahul Muluk Papua
}

\begin{abstract}
ABSTRAK
Artikel ini bertujuan untuk mengetahui tentang mengapa masyarakat suku Bugis masih mempertahankan tradisi Ininnawa dalam mendidik anak-anaknya di Kampung Kukup. Merupakan penelitian deskriptif kualitatif dengan paradigma fenomenologi social. Hasil penelitian: Tradisi Ininnawa merupakan tradisi yang memiliki manfaat bagi generasi suku Bugis di Kampung Kukup dalam memelihara dan memperbaiki serta memotivasi pengembangan budaya, merupakan kebutuhan untuk menjaga generasinya dalam lingkaran kebaikan tentang bagaiamana menghadapi, menanggulangi tantangan zaman. Tujuan Ininnawa adalah harapan bagi generasi Bugis yang ada di Kampung Kukup mampu menyesuaikan diri dengan lingkungan, menyesuaikan lingkungan dengan kebutuhannya. Ininnawa merupakan pembelajaran dalam pembentukan kecakapan secara intelektual, suatu prinsip yang nanti dipegang teguh pada masa kedewasaan yaitu sebuah "Kesungguhan" dan "Rasa Malu", ditanamkan dalam diri semangat keberhasilan. Pelaksanaan tradisi merupakan pelestarian budaya berlangsung dari masa ke masa terarah, terpadu secara dinamis, merupakan cara hidup masyarakat yang merupakan warisan turun temurun, mengandung filosofi tentang cara berfikir, merasa, serta percaya berkaitan dengan tingkah laku dalam bermasyarakat yang terkandung dalam falsafah Sipakatau (Tidak saling membeda-bedakan), Sipakainge (Saling mengingatkan), Sipakalebbi (Saling menghargai). Tradisi Ininnawa merupakan sebuah kebiasaan-kebiasaan baik yang berkaitan dengan kepribadian, sikap sosial dalam kehidupan bermasyarakat. Tradisi ini selaras dengan ajaran Islam yang mengajarkan tentang akhlak yang baik sesuai dengan tuntutan AlQur'an dan Hadits.
\end{abstract}

Kata Kunci: Ininnawa, Pendidikan Karakter, Suku, Bugis 


\begin{abstract}
This research aimed to understand the Ininnawa tradition maintained by the Bugis people of nurturing their children in Kukup Village. The method used in this research was qualitative descriptive with a social phenomenology paradigm. Research findings: the Ininnawa tradition is a tradition where has a benefit for the Bugis generation in improving and maintaining cultural preservation to keep them facing and overcoming challenges. The Ininnawa tradition aims to increase the Bugis people's ability to adapt to their surroundings. This tradition is learning to develop intellectual skills and a principle firmly entrenched in adulthood about "seriousness" and "shame" in the spirit of success. The Ininnawa tradition is a hereditary inheritance from the Bugis people that is to be done from time to time in their lives as a way of preserving the culture that has a philosophy of thinking, feeling, and believing to behavior in society, which includes Sipakatau (not distinguish each other), Sipakainge (recognizing each other), and Sipakalebbi (mutual respect). The Ininnawa tradition exemplifies personality and social attitudes in everyday life. This tradition is consistent with Islamic teachings, which aim to instill good morals by the requirements of the Qur'an and Hadith.
\end{abstract}

Keywords: Ininnawa, Character Building, Tribe, Bugis

\title{
A. PENDAHULUAN
}

Negara Indonesia menjadi besar karena mempunyai keragaman budaya dan tradisi yang kaya akan nilai religius dan sosialnya sehingga mampu membuat nilai persatuan menjadi stagnan dan menjadi aset terbesar bangsa ini. Namun seiring dengan bergulirnya zaman menjadikan nilai tersebut terancam keabsahannya terutama dalam sektor pendidikan.

Dikatakan dalam (UU No. 20 Tahun 2003 tentang Sistem Pendidikan Nasional, JDIH BPK RI) pasal 1 bahwa: Pendidikan merupakan susunan konsep gramatikal yang sangat berperan dalam menyusun strukstur perkembangan dalam kehidupan manusia dan tentunya menjadi salah satu tolak ukur penilaian terhadap suatu Bangsa. Dengan ini tentunya pendidikan harus menjadi aspek yang mendapat perhatian lebih guna pengembangan kualitas pendidikan yang di inginkan, bahwa Pendidikan merupakan usaha sadar serta terencana agar menciptakan suasana belajar serta proses pembelajaran supaya peserta didik dengan aktif mengembangkan potensi dirinya agar mempunyai kekuatan spiritual keagamaan, pengendalian diri, kepribadian, kecerdasan akhlak mulia, dan ketrampilan yang dibutuhkan dirinya, masyarakat, Bangsa dan Negara.

Dewasa ini pendidikan cenderung dipandang sebagai sesuatu yang bersifat praktis bukan lagi kepada sesuatu yang realistis atau nyata. Dampaknya kepada implementasi pendidikan, yang akan nampak tidak efektif berjalan terlebih lagi pada sistem pendidikan di ranah non-formal yang tidak begitu memperhatikan unsur-unsur penyusunan dari sistem pendidikan itu sendiri. Dan tentu saja implementasi pendidikan dengan model seperti ini juga tidak 
akan berjalan baik dan tidak akan mewujudkan tujuan pendidikan yang sebenarnya.

Sejatinya pendidikan itu bukan hanya sebatas mentransfer ilmu pengetahuan dari guru pada peserta didik atau hanya proses dari tidak tau menjadi tau, melainkan lebih dari itu, yaitu mentransfer nilai dari pengetahuan itu sendiri. Pendidikan juga merupakan gerak dari sebuah kultur yang menuntut kepada siswa agar selalu mengembangkan potensi dalam dirinya agar mampu bersaing dan terus berkembang di dalam kehidupannya. Karena itulah, daya kritis siswa dan partisipatifnya hendaknya selalu timbul dalam jiwa peserta didik. Lantas jika proyeksi pembelajaran tidak mendukung untuk mewujudkan hal tersebut, maka tidak akan terwujud pula tujuan pendidikan sebagaimana yang diharapkan. Terlebih lagi sistem pendidikan di bangsa ini yang mengalami distorsi pemerataan, namun di tuntut keras dengan kualitas yang harus berujung kepada kesetaraan. Maka dengan melihat klausa ini dapat dikatakan bahwa kapita selekta pendidikan bangsa ini begitu banyak yang harus di selesaikan, yang juga begitu menghambat terwujudnya tujuan pendidikan yang diharapkan sebagaimana mestinya.

Selain itu telah menjadi rahasia umum bagi kita semua bahwa dizaman milenial ini, siswa/pelajar Indonesia telah banyak yang terjerumus kedalam perilaku kenakalan yang telah melampaui batas. Bahkan, keterbukaan informasi sejak era reformasi dimulai ditambah derasnya arus era globalisasi menyebabkan berbagai macam keburukan siswa semakin kelihatan wujudnya. Kondisi ini tentunya sangat bertentangan dengan karakter bangsa yang berbudaya dan beragama serta tidak sejalan dengan tujuan pendidikan nasional seperti yang ditetapkan dalam undang-undang, bahwa sejatinya peserta didik merupakan cikal bakal tumbuhnya nilai-nilai luhur dan menjadi generasi yang akan mewujudkan cita-cita bangsa.

Sejauh ini pendidikan Islam selalu di gaungkan sebagaia solusi tepat dalam penyelesaian masalah pendidikan di Negara ini, bahwa Pendidikan Islam adalah system pendidikan yang mampu menyuguhkan kemampuan seseorang agar memimpin kehidupannya sesuai dengan cita-cita serta nilai-nilai Islam yang sudah menjiwai serta member warna corak kepribadiannya. Arifin (2008) mengatakan pendidikan agama islam merupakan sebuah system kependidikan yang meliputi keseluruhan aspek kehidupan yang dibutuhkan oleh hamba Allah, sebagaimana Islam telah menjadi pedoman bagi seluruh aspek kehidupan manusia, baik duniawi maupun ukhrawi. Mujib (2006) mengatakan selaras dengan tujuan akhirnya, yakni terciptanya insan Kamil, yaitu manusia yang dapat menyeimbangkan serta keterpenuhan hajat hidup jangka pendek misalnya keterpenuhan kebutuhan duniawi, namun juga keterpenuhan hajat hidup jangka panjang misalnya keterpenuhan kebutuhan di akhirat kelak.

Salim (2018) mengatakan: Dalam kaitannya, sudah menjadi fitrah bagi setiap manusia khususnya dalam entitas suatu kelompok, bahwa akan selalu mengusahakan pemberian orientasi pembelajaran kepada generasinya yang memiliki tujuan agar melestarikan budaya mereka, serta menyesuikan diri dengan lingkungannnya. Tak terkecuali suku bangsa bugis yang dikenal sebagai suku pelaut dengan ragam tradisinya.

Akhmad (2005) mengatakan suku bangsa Bugis merupakan satu etnik di Indonesia yang termasuk ke dalam rumpun keluarga besar Austronesia yang menempati bagian selatan pulau Sulawesi. Saat ini populasinya lebih dari tiga 
juta orang. Namun sebagian lainnya sudah bermigrasi ke daerah lainnya teresebut dan tersebar hingga ke seluruh penjuru NUsantara. Kondisi Sosial seperti inilah yang menunjukan betapa luasnya pengaruh serta ruang geografis perantau Suku Bugis hingga saat ini. Namun, sekalipun demikian suku Bugis terus menyesuaikan posisi mereka dengan kondisi di sekitarnya, orang Bugis tetap dapat mempertahankan identitas "Kebugisannya".

Gambaran ini dapat kita jumpai di lingkungan masyarakat Bugis daerah Kukup Kampung Koya Koso Distrik Abepura Kota Jayapura. Keasrian lingkungannya, bahasanya, hingga bangunan tempat tinggal mereka yang betulbetul persis dengan yang ada di daerah asalnya sulawesi selatan. Budaya Bugisnya tidak hilang sekalipun berada di ujung timur Nusantara, Salah satunya adalah Ininnawa, bagaimana para orang tua merawat dan membesarkan serta mendidik anak-anaknya dengan ketulusan, bahkan para orang tua di suku Bugis tersebut juga memperhatikan dan merawat seluruh anak-anak yang ada di lingkungan sekitar mereka terlebih yang satu suku juga dengan mereka, sehingga para anak-anak dari suku Bugis di dareah kukup tersebut sangat diperhatikan perihal akhlak, tingkah laku, dan pendidikannya. Mendidik dan membesarkan anak dengan ketulusan dan niatan yang baik untuk mencapai tujuan yang baik pula merupakan nilai utama dari Ininnawa, anak keturunan suku Bugis harus tumbuh dan berkembang dengan kemampuan yang jauh lebih baik dibandingkan orang tuanya sehingga kelak tradisi warisan leluhur, petuah dari tetuah, serta nilai kebajikan dan juga rahmat Tuhan Yang Maha Esa akan tercurahkan dalam masyarakat suku Bugis karena tetap menggulirkan nilai kebaikan secara turun temurun dalam kehidupannya. Tradisi ini betul-betul mencerminkan sebuah nilai seperti yang diajarkan dalam Islam, dan dari uraian diatas pula dapat diketahui bahwa suku Bugis memiliki sebuah estetika didalam kebudayanya tentang pendidikan terlebih lagi dalam mengatasi problema global pendidikan yang terjadi di Indonesia saat ini. Tujuan dari artikel ini adalah : Untuk mengetahui tentang mengapa masyarakat suku Bugis masih mempertahankan tradisi Ininnawa dalam mendidik anak-anaknya di Kampung Kukup.

Penelitian yang pernah dilakukan sebelumnya diantaranya adalah sebagai berikut. Suhra (2019) mengatakan terdapat beberapa nilai pendidikan karakter (pappaseng) seperti: peduli, toleransi dan demokrasi, jujur, bersih, dan sabar, Karakter kesabaran dalam (elong) berbunyi: (Ininnawasabbarakki lolongeng gare Deceng enrekki ri bola tejjali tettappere banna mase-mase).

Priyatna (2017) mengatakan berbagai fakta yang memiliki hubungan dengan kampung Adat Pulo, maka mampu disimpulkan bahwa masyarakat kampung Adat Pulo adalah Kampung adat yang hingga saat ini tetap eksis mempertahankan tradisi yang sudaj diwariskan leluhurnya. Hal ini disebabkan karena mereka masih mempunyai aturan adat yang jika dilanggar akan memperoleh sanksi adat, sanksi adat tersebut diyakini karena sifatnya yang sacral. Bentuk karakter yang dimiliki sebagai hasil dari proses internalisasi nilai serta mampu dipromosikan sebagai basis pembentuk karakter Bangsa Indonesia merupakan, karakter Religius, Jujur, Toleransi, Disiplin, Kerja Keras, Mandiri, Demokrasi, Bersahabat/Komunikatif, Cinta damai, peduliLingkungan, Peduli Sosial, juga Tanggung-jawab.

Norianda, et.al. (2021) mengatakan budaya sekolah Jumat Berkah memiliki nilai religious, nasionalisme, kreativitas serta gotong royong yang 
mampu diinternalisasikan untuk peserta didik sebagai upaya agar membantu memperbaiki karakter. Karakter yang mampu dibentuk melalui budaya sekolah Jumat Berkah merupakan karakter tangguh, bersih serta sehat, disiplin, peduli lingkungan, kerja sama, tanggung jawab, kreatif dan tolong menolong.

Perbedaan artikel ini dengan artikel tersebut diatas terletak pada Suku Bugis yang tetap mempertahankan tradisi Ininnawa yang merupakan pendidikan karakter secara turun temurun di daerah perantauan pada generasi mudanya.

Teori yang memperkuat artikel ini diantaranya sebagai berikut. Jhon Dewey dalam Yusuf, et.al. (2021) mengatakan pendidikan merupakan proses pembentukan berbagai kecakapan fundamental secara intelektual serta emosional menuju alam serta sesama manusia. S.A. Bratanata dalam Yusuf, et.al. (2021) mengatakan pendidikan merupakan usaha yang sengaja dilakukan baik langsung maupun melalui cara yang tidak langsung agar membantu anak dalam perkembangannya mencapai kedewasaannya.

Parson dalam Yusuf, et.al. (2021) mengatakan suatu fungsi adalah "Berbagai kegiatan yang ditujukan kearah keterpenuhan kebutuhan tertentu atau kebutuhan system". Lebih jauh dijelaskan bahwa : Terdapat empat fungsi utama dibutuhkan semua system-adaptation (A), goal attainment (G), integration (I), dan latensi (L) atau pemeliharaan pola. Secara bersama-sama, keempat imperative fungsional ini dikenal sebagai skema AGIL. Agar tetap bertahan (survive), suatu system hendaknya mempunyai empat fungsi sebagai berikut.

1. Adaptation (adaptasi), sebuah system hendaknya mengatasi situasi eksternal yang gawat. Sistem harus melakukan penyesuaian diri pada lingkungannya serta menyesuaikan lingkungan tersebut dengan kebutuhannya;

2. Goal attainment (pencapaian tujuan), sebuah system hendaknya menjabarkan serta mencapai tujuan utamanya;

3. Integration (integrasi), sebuah system hendaknya menata antar hubungan berbagai bagian yang merupakan komponennya. Sistem juga hendaknya melakukan pengelolaan antar hubungan ketiga fungsi penting lainnya $(\mathrm{A}, \mathrm{G}, \mathrm{L})$;

4. Latency (latensi atau pemeliharaan pola), sebuah system hendaknya memperlengkapi, memelihara serta melakukan perbaikan, baik motivasi individual ataupun berbagai pola kultur yang menghasilkan serta menopang motivasi.

Clyde Kluckhohn dalam Geertz (1992:4) mengatakan kebudayaan merupakan: (1) keseluruhan cara hidup suatu masyarakat, (2) warisan social yang didapatkan individu dari kelompoknya, (3) merupakan cara berpikir, merasa serta percaya, (4) merupakan abstraksi dari tingkah laku, (5) merupakan teori pada pihak antropologi mengenai metode suatu kelompok masyarakat pada kenyataannya bertingkah laku, (6) merupakan gudang untuk menampung hasil belajar, (7) seperangkat orientasi-orientasi standart pada masalah-masalah yang sedang berjalan, (8) tingkah laku yang dipelajari, (9) merupakan mekanisme untuk penataan tingkah laku yang memiliki sifat normative, (10) seperangkat tehnik untuk melakukan penyesuaian baik dengan lingkungan luar ataupun dengan orang-orang lain, (11) suatu endapan sejarah 
dan mungkin dengan putus asa beralih ke kiasan-kiasan, merupakan sebuah peta, suatu penyaring, serta sebagai sebuah matriks.

Berdasarkan tujuan penulisan yang dasarnya adalah menjelaskan fenomena Ininnawa pada masyarakat Kukup di Kampung Koya Koso Kota Jayapura, maka jenis tulisan ini adalah deskriptip kualitatif. Suharsimi Arikunto, dalam Yusuf, et.al. (2021) mengatakan metode dalam penulisan kualitatif mengarah pada penegasan serta penjabaran yang mengarah pada prosedur-prosedur umum seperti alasan (1) pendekatan ini digunakan (2) unit analisis (3) metode pengumpulan data serta (4) keabsahan data. Paradigma penulisan kualitatif yang digunakan adalah: Fenomenologis Sosial Schutz dan Luckman dalam Nawir, et.al. (2020) mengatakan fenomenologi sosial dimaksudkan untuk merumuskan ilmu sosial yang dapat 'memperkirakan serta menjabarkan tindakan dan pemikiran manusia' melalui cara mendeskripsikan struktur-struktur dasar....kenyataan yang tampak 'nyata' dimata setiap orang yang berpedoman pada 'sikap alamiah. Penulisan ini terpusat pada makna serta pengalaman subjektif sehari-hari, yang memiliki tujuan menjabarkan bagaimana objek serta pengalaman terwujud dengan penuh makna, dikomunikasikan pada kehidupan sehari-hari.

Setting dilakukan di Kampung Kukup Koya Koso Distrik Abepura Kota Jayapura. Instrumen kunci adalah masyarakat suku Bugis Kampung Kukup Koya Koso dan penulis sendiri. Sumber data yang digunakan pada penulisan ini merupakan data primer serta sekunder. Data primer yaitu data yang didapatkan langsung dari informan. Sedangkan data sekunder merupakan data yang didapatkan melalui studi dokumentasi, dalam bentuk hasil-hasil laporan baik pada saat berada dilapangan penulisan, ataupun ketika berada ditempat lain, semuanya itu memiliki relevansi dengan obyek penulisan.

Beberapa cara yang ditempuh agar memperoleh data lapangan, yaitu: dengan melaksanakan observasi partisipatoris. Pada kegiatan observasi partisipatoris tersebut, yaitu peneliti melaksanakan aktivitas pemusatan perhatian pada suatu obyek dengan seluruh panca indra mengenai gejala-gejala tertentu melalui cara pengamatan langsung sehingga penulis mengetahui langsung obyek yang diteliti. Peneliti ikut ambil bagian dengan aktivitas Ininnawa di Kampung Kukup Koya Koso Distrik Abepura Kota Jayapura, serta peneliti berpartisipasi pada aktivitas serta melaksanakan pengamatan langsung. Selain itu dilakukan juga In-depth Interview, penulis melakukan dialog atau wawancara agar mendapatkan data yang diteliti yang diperoleh melalui informan atau narasumber, secara lebih bebas, agar memperoleh permasalahan lebih terbuka, menggunakan wawancara tidak berstruktur, juga melakukan sesi dokumentasi. Menggunakan tehnik analisa data yang dijabarkan Miles dan Huberman yang dikutip Yusuf, et.al. (2020) yang mengatakan sebagai berikut. Tehnik menganalisis data dengan cara membaginya kedalam tiga tahapan sebagai berikut. Reduksi Data: melakukan perangkuman data, memilah mengenai berbagai hal yang dipandang pokok, focus kepada berbagai hal yang dipandang penting, juga membuang berbagai hal yang dipandang tidak penting; Data Display (Penyajian Data): membuat catatan/penjabaran singkat, bagan, hubungan diantara kategori dan sejenisnya; Conclusing Drawing/Verification: Penarikan kesimpulan dan verivikasi. 


\section{B. TRADISI ININNAWA PADA MASYARAKAT SUKU BUGIS DI KAMPUNG KUKUP KOYA KOSO}

\section{Fungsi Ininnawa}

a. Sebagai Pendidikan Karakter Bagi Anak

Ininnawa merupakan bagian kecil dari beragamnya tradisi suku Bugis yang nantinya akan sangat membantu kehidupan suku Bugis dimanapun mereka berada atau menjalani hidup. Hal ini juga Sangat berguna bagi pembentukan karakter bagi anak cucu generasi dalam suku Bugis karena akan membentuk sebuah nilai kebaikan yang akan dijalaninya kelak.

Sejalan dengan pendapat itu, dijelaskan oleh informan Bapak Muh.Nur selaku ketua RW.o2 di Kampung Kukup tersebut yang juga berasal dari Bone dan juga merupakan salah satu dari orang-orang yang ikut membangun di masa awal terbentuknya Kampung Kukup yang mengatakan sebagai berikut:

"Ininnawa mengajarkan sebuah nilai pendidikan karakter didalamnya bagi anak cucu generasinya, ketika seorang anak dari suku Bugis menjalani kehidupan sosialnya maka akan ada sebuah nilai Ininnawa yang mereka terapkan mulai dari saling Menghargai, Menasehati dalam kebaikan, dan saling Menghormati satu sama lainnya. Sehingga akan ada timbal balik yang dirasakannya mulai dari diterima dimanapun suku Bugis ini berada, akan di hormati dan disanjung pula karena kelakuannya, serta mampu menjadi pengaruh baik bagi masyarakat yang ada disekitarnya. Inilah bagian kecil dari manfaat tradi Ininnawa suku Bugis."

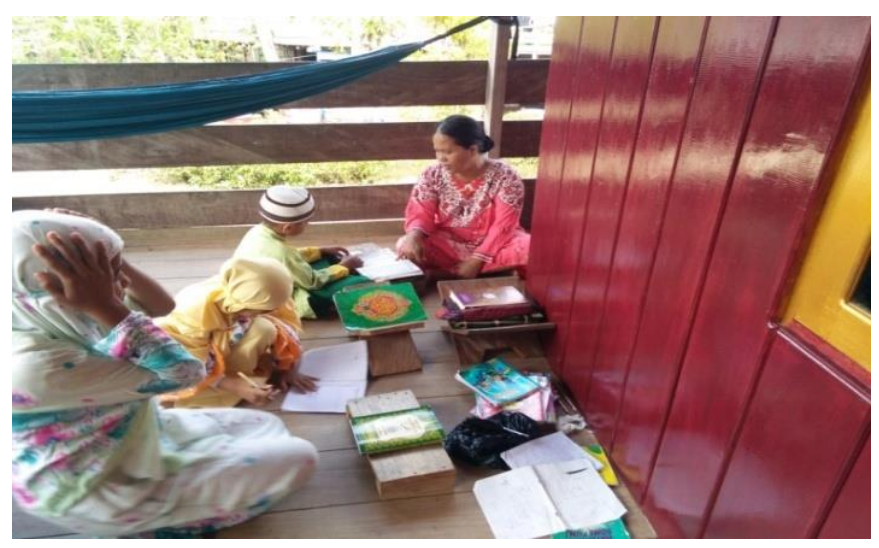

Gambar 1. Pelaksanaan Pelajaran Karakter Sumber : Dokumen Pribadi

Parson dalam Yusuf, et.al. (2021) mengatakan suatu fungsi adalah "Berbagai kegiatan yang ditujukan kearah keterpenuhan kebutuhan tertentu atau kebutuhan system". Lebih jauh dijelaskan bahwa : Terdapat empat fungsi utama dibutuhkan semua system - adaptation (A), goal attainment (G), integration (I), dan latensi (L) atau pemeliharaan pola. Secara bersama-sama, keempat imperative fungsional ini dikenal sebagai 
skema AGIL. Agar tetap bertahan (survive), suatu system hendaknya mempunyai empat fungsi sebagai berikut.

1) Adaptation (adaptasi), sebuah system hendaknya mengatasi situasi eksternal yang gawat. Sistem harus melakukan penyesuaian diri pada lingkungannya serta menyesuaikan lingkungan tersebut dengan kebutuhannya;

2) Goal attainment (pencapaian tujuan), sebuah system hendaknya menjabarkan serta mencapai tujuan utamanya;

3) Integration (integrasi), sebuah system hendaknya menata antar hubungan berbagai bagian yang merupakan komponennya. Sistem juga hendaknya melakukan pengelolaan antar hubungan ketiga fungsi penting lainnya $(\mathrm{A}, \mathrm{G}, \mathrm{L})$;

4) Latency (latensi atau pemeliharaan pola), sebuah system hendaknya memperlengkapi, memelihara serta melakukan perbaikan, baik motivasi individual ataupun berbagai pola kultur yang menghasilkan serta menopang motivasi.

Tradisi Ininnawa merupakan sebuah system yang memiliki manfaat yang nantinya akan dirasakan bagi anak generasi suku Bugis di Kampung Kukup dalam memelihara dan memperbaiki serta memotivasi pengembangan budaya. Hal ini pun akan sangat menguntungkan bagi masyarakat suku Bugis sendiri karena hal ini merupakan kebutuhan untuk dapat menjaga generasinya agar tetap berada dalam lingkaran kebaikan dan juga mendapatkan sebuah jaminan tentang bagaiamana menghadapi serta menanggulangi tantangan zaman, dimana tujuan dari Ininnawa adalah adnya harapan bagi generasi Bugis yang ada di Kampung Kukup mampu menyesuaikan diri dengan lingkungan juga menyesuaikan lingkungan tersebut dengan kebutuhannya.

b. Sebagai Pembelajaran Bagi Anak Agar Dapat Menjadi Lebih Baik Dari Sebelumnya

Pengaruh globalisasi tentunya akan selalu mengubah sebuah pola kehidupan dari masa kemasa, tak terkecuali pada kehidupan masyarakat suku Bugis. Tradis Ininnawa sangat berguna bagi keberlangsungan kehidupan generasi masyarakat suku Bugis nantinya karena mengajarkan sebuah nilai tentang bagaimana anak-anak dari suku Bugis harus mampu mencapai kehidupan yang jauh lebih baik dari sebelumnya (orang tuanya). Seperti yang diungkapkan informan Bapak Haji Bakri juga menambahkan dalam penjelasannya terkait cara mendidik dan masalah anak di era globalisasi, yang mengatakan sebagai berikut.

"....Tidak bisami kayak dulu, Sehingga sistem penempaan atau didikan orang tua dalam suku Bugis kepada anak-anak mereka cukup keras, dimana seorang anak harus dituntut mampu bekerja dan berfikir 2 kali lipat dibanding orang tuanya. Hal ini tergambar dari kehidupan anak-anak suku Bugis di Kampung Kukup Koya Koso Kota Jayapura, contohnya ketika mereka sehabis pulang dari sekolah pukul 14.00 siang bukannya langsung istirahat melainkan harus lanjut untuk belajar lagi mengenai Al-Qur'an dan pelajaran Agama yang tidak 
didapatkannya di sekolah. Selain itu ada juga yang ikut berkebuh bersama orang tua mereka yang jaraknya begitu jauh dari rumah tempat tinggalnya."

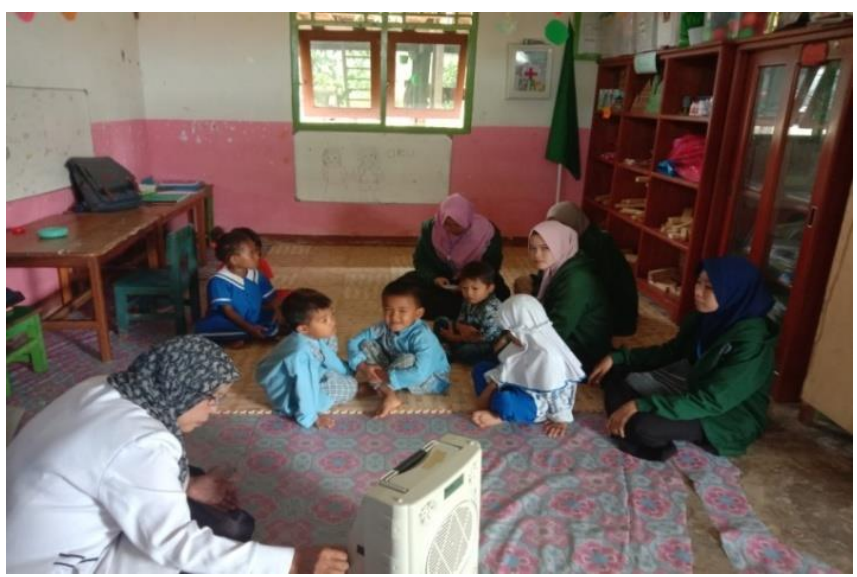

Gambar 2. Pembelajaran Yang Didampingi Pendidik

Sumber : Dokumen Pribadi

Jhon Dewey dalam Yusuf, et.al (2021) mengatakan pendidikan merupakan proses pembentukan berbagai kecakapan fundamental secara intelektual serta emosional menuju alam serta sesama manusia. S.A. Bratanata dalam Yusuf, et.al. (2021) mengatakan pendidikan merupakan usaha yang sengaja dilakukan baik langsung maupun melalui cara yang tidak langsung agar membantu anak dalam perkembangannya mencapai kedewasaannya.

Ininnawa bertujuan bukan untuk menyiksa atau tidak sayang kepada anak-anak mereka, melainkan sebuah pembelajaran dalam rangka pembentukan kecakapan-kecakapan secara intelektual serta mengasah emosional untuk membantu bagi generasinya tentang suatu prinsip yang nanti harus mereka pegang teguh pada masa kedewasaan yaitu sebuah "Kesungguhan" dan "Rasa Malu", karena bagi masyarakat suku Bugis pantang untuk mengeluh sekalipun harus basah membasuh peluh, sehingga sangat ditanamkan didalam diri mereka tentang semangat untuk selalu berhasil. Hal ini tercermin dalam prinsip para pelaut suku Bugis yang berbunyi pura ba'barasompe'ku, pura tangkisi' gulikku, ulebbireng telleng na toalie" Bilamana layarku sudah ku kembangkan, kemudiku telah kupancangkan, maka lebih baik tenggelam dari pada balik surut (kepantai).

\section{Melestarikan Budaya}

\section{a. Pembelajaran Tentang Budaya Lokal}

Pembelajaran tentang suatu kebudayan dalam masyarakat sangat dibutuhkan agar mampu mempertahankan kebudayaan tersebut sehingga terhindar dari kemusnahan dari ciri khas sebuah masyarakat. Begitu pula dengan masyarakat Bugis di Kampung Kukup yang masih mempertahankan tradisi inninawa pada masyarakatnya untuk tetap terpelihara walaupun berada di daerah perantauan. 
Sedyawati (2006:28) mengatakan pembelajaran mengenai budaya, hendaknya ditanamkan semenjak dini. Akan tetapi saat sekarang banyak yang sudah tidak peduli untuk mempelajari budaya lokal. Hal tersebut dibuktikan melalui rencana pembangunan pemerintah, bidang sosial budaya masih terdapat porsi yang amat kecil. Padahal melewati pembelajaran budaya, kita mampu mengetahui urgennya budaya lokal dalam membangun budaya bangsa juga bagaiman tehnik mengadaptasikan budaya lokal di tengah kemajuan zaman pada era globalisasi. Seperti yang diungkapkan informan Bapak Haji Bakri selaku tokoh adat suku Bugis di kampung tersebut yang mengatakan sebagai berikut.

"Mau bagaiamanapun majunya zaman, dan betapa mengerikannya dampak kepada anak-anak kita kalau kita sebagai orang tua mampu menjelaskan dan membuat nilai kebaikan kepada anak-anak kita terus ada, insya Allah akan selalu berbuah kebaikan pula dan sekaligus dapat membantu melestarikan dan mengajarkan kepada anak-anak kita kalo Bugis ini punya keunikan didalmnya salah satunya Ininnawa”

Clyde Kluckhohn dalam Geertz (1992:4) mengatakan kebudayaan merupakan: 1). keseluruhan cara hidup suatu masyarakat, 2). warisan social yang didapatkan individu dari kelompoknya, 3). merupakan cara berpikir, merasa serta percaya, 4). merupakan abstraksi dari tingkah laku, 5). merupakan teori pada pihak antropologi mengenai metode suatu kelompok masyarakat pada kenyataannya bertingkah laku, 6). merupakan gudang untuk menampung hasil belajar, 7). seperangkat orientasi-orientasi standart pada masalah-masalah yang sedang berjalan, 8). tingkah laku yang dipelajari, 9). merupakan mekanisme untuk penataan tingkah laku yang memiliki sifat normative, 10). seperangkat tehnik untuk melakukan penyesuaian baik dengan lingkungan luar ataupun dengan orang-orang lain, 11). suatu endapan sejarah dan mungkin dengan putus asa beralih ke kiasan-kiasan, merupakan sebuah peta, suatu penyaring, serta sebagai sebuah matriks.

Kebaikan akan selalu hadir membuahkan kebaikan juga, pelaksanaan tradisi ini juga sekaligus dapat menjalankan sebuah giat pelestarian kebudayaan. Maka dapat dikatakan bahwa tradisi ini memang diharapkan mendapatkan rahmat dari Allah SWT dan mendapatkan penjagaan dan dapat berlangsung dari masa ke masa dimana didalamnya merupakan cara hidup suatu masyarakat yang merupakan warisan secara turun temurun dari leluhurnya, yang mengandung filosofi tentang cara berfikir, merasa serta percaya berkaitan dengan tingkah laku dalam bermasyarakat yang terkandung dalam falsafah Sipakatau (sifat yang tidak saling membeda-bedakan), Sipakainge (Sifat dimana kita saling mengingatkan), Sipakalebbi (Sifat saling menghargai sesama manusia), yang merupakan pembelajaran bagi generasi muda Bugis di Kampung Kukup dalam menghadapi berbagai permasalahan yang nantinya bakal dihadapi dalam kehidupannya. 


\section{b. Upaya-upaya Dalam Melestarikan Budaya}

Masyarakat Bugis perantau yang ada di Kampung Kukup berusaha untuk tetap melestarikan budaya leluhurnya yang merupakan kebaikankebaikan yang diajarkan secara turun temurun dari satu generasi ke generasi lainnya sehingga tidak mudah ditelan zaman, terlebih ketika arus globalisasi melanda dunia yang mampu memporakporandakan berbagai tradisi yang menopang kehidupan masyarakat.

Sejalan dengan hal itu, disampaikan oleh informan Bapak Haji Bakri dan Juga Bapak Haji Tahir ketika mendengar pembahasan ini beliau selaku orang yang dituakan dan juga orang terhormat karena peran dan kontribusi dalam mendirikan kampung tersebut, yang mengatakan sebagai berikut.

"Seandainya bukan karena kesadaran dan memang Ininnawa ini punya nilai kebaikan, mungkin sudah lupa kita ini dengan budayanya kita sendiri apalagi kita ini jauh dari tempat asal"

Sejurus dengan pendapat tersebut diatas, diutarakan pula oleh informan Bapak Haji Tahir yang juga merupakan sesepuh Kampung Kukup, yang mengatakan sebagai berikut.

"Anak generasi kita itu harus tau dan paham betul tentang nilainilai kebaikan dalam budaya kita karena itu mi juga nanti yang akan bantu mereka untuk didik anak-anaknya"

Nahak (2019:72) mengatakan pelestarian merupakan aktivitas atau yang dilaksanakan secara continue, terarah serta terpadu untuk mewujudkan tujuan yang telah ditentukan yang bercirikan adanya sesuatu yang tetap serta abadi, memiliki sifat dinamis, luwes, serta selektif. Pelestarian budaya merupakan usaha agar mempertahankan nilai-nilai seni budaya, nilai tradisional melalui pengembangan perwujudan yang memiliki sifat dinamis, luwes dan selektif, serta melakukan penyesuaian melalui situasi serta kondisi yang selalu berubah dan berkembang.

Widjaja yang dikutip Ranjabar (2006:56) mengartikan pelestarian merupakan aktivitas atau yang dilaksanakan secara continue, terarah serta terpadu dalam merealisasikan tujuan yang telah ditentukan yang mencerminkan terdapat sesuatu yang tetap dan abadi, memiliki sifat dinamis, luwes serta selektif.

Adanya sebuah kesadaran dari para orang tua dalam suku Bugis di Kampung Kukup ini tentang menerapkan nilai kebaikan kepada anakanaknya dan juga membuat tradisi ini terus bergulir dan diterapkan dari masa ke masa terarah dan terpadu secara dinamis dalam rangka membuat seluruh kehidupan dilingkungan mereka menjadi baik. Suku Bugis mempunyai kebudayaan yang kental dengan nilai kebaikan sesuai dengan norma-norma yang berlaku dilingkungan secara umumnya. Tidak ada hal yang lebih ditinggikan oleh msyarakat suku Bugis ini selain kebudayaannya, karena itulah yang menjadi pedoman mereka dimanapun berada. Ininnawa yang dilakukan di Kampung Kukup adalah dalam rangka mempertahankan nilai-nilai budaya tradisional masyarakat Bugis dalam rangka mempersiapkan diri generasi Bugis di 
Kampung Kukup menyikapi situasi dan kondisi kehidupan yang selalu berubah.

c. Kebiasaan Menerapkan Tradisi Ininnawa di Kampung Kukup Koya Koso

Dengan masih di praktikkannya tradisi Ininnawa di kampung kukup koya koso ini menjadi suatu bukti bahwa tradisi ini tidak akan lekang oleh waktu dan akan terus menebarkan manfaat kebaikannya dalam setiap generasi dalam suku Bugis, dimana tradisi ini dianggap sangat bermanfaat bagi masyarakat kampung dan dilakukan secara turun temurun. Selaras dengan itu, diungkapkan oleh informan Bapak Haji Bakri juga menerangkan terkait Ininnawa tersebut, yang mengatakan sebagai berikut.

"Sudah menjadi kebiasaan dalam suku Bugis ini perihal membesarkan anak dengan Ininnawa, karena dengan itu mereka mampu mendidik anak-anak mereka dengan baik serta dapat menjaga warisan tradisi dalam suku mereka yang nantinya dapat di gunakan juga oleh generasi selanjutnya, Kampung kukup koya koso menjadi bukti tentang tangguhnya dan betapa menariknya suku Bugis ini dalam menjalani hidup. Berada jauh dari tempat asalnya bukan menjadi penghalang dalam menerapkan nilai kebudayaan, Karena dimana kaki berpijak disana langit dijunjung”.

Pembiasaan tentang bagaimana berprilaku yang baik sangat dibutuhkan bagi setiap manusia terutama ditekankan sejak kecil dimana akan terekam jejak pembiasaan tersebut hingga dewasa. Charles Horton Cooley yang dikutip Roucek, et.al. (1984:286) dalam teorinya tentang kepribadian menjelaskan kesadaran sosial tidak mampu diasingkan dari kesadaran diri, seorang individu merupakan suatu abstrak yang tidak diketahui melalui pengalaman, dan begitu juga dengan masyarakat jika dipandang sebagai sesuatu yang berbeda dari pada individu. Kehidupan merupakan keseluruhan organik. Anak-anak berada dibawah pengawasan kelompok inti, keluarga, kelompok sepermainan dan tetangga. Kelompok inti ini dengan hubungan mesra antara jiran adalah menjadi matriks bagi sifat kepribadian dan sikap sosial”.

Tradisi Ininnawa ini bukanlah sebuah tradisi yang biasa dalam kebudayaan suku Bugis. Dimana tradisi ini merupakan sebuah kebiasaan-kebiasaan baik yang diturunkan oleh leluhur yang berkaitan dengan kepribadian dan sikap social dalam kehidupan bermasyarakat. Tradisi ini mampu menyelaraskan tugas pokok dan fungsinya untuk mengikuti zaman serta dapat ikut menjadi sebuah kebaikan dimanapun dan kapanpun tradisi ini diterapkan, yang merupakan kesadaran social dari masyarakat Bugis di Kampung Kukup. Segala sesuatu apabila dimulai dengan kebaikan akan menghasilkan sebuah kebaikan pula. Kebudayaan memang selalu penuh dengan sebuah hal yang menarik, tak terkecuali kebudayaan suku Bugis ini yang dapat dijadikan sebagai sebuah pelajaran dalam kehidupan. 


\section{Ininnawa Dalam Ajaran Islam}

Ininnawa mengajarkan sebuah akhlak didalamnya, dari seluruh unsur penyusunnya sampai kepada hasil dari Ininnawa nantinya. Hal ini sejalan dengan apa yang diajarkan Agama Islam dan tujuannya atau alasan di utusnya Rasulullah SAW kedunia. Akhlak yang baik sangat penting dalam kehidupan sehari-hari, karena dengan akhlak tersebut dapat menyeimbangkan antara akhlak yang baik dengan akhlak yang buruk pada perbuatan manusia, maka ukuran dan karakternya akan selalu terlihat dinamis atau berubah-ubah.

Nata (2000:168-170) mengatakan Islam mengharapkan suatu kelompok masyarakat yang memiliki akhlak mulia. Akhlak mulia tersebut sangat diperhatikan dalam Islam disebabkan karena di samping akan mengantarkan kebahagiaan pada individu, juga secara bersama mengantarkan kebahagiaan untuk masyarakat pada umumnya. Dengan pengertian lain bahwa akhlak utama yang diperlihatkan individu, memiliki tujuan agar memperoleh kebahagiaan di dunia serta di akhirat.

Allah SWT menggambarkan dalam al-Qur'an tentang janji-Nya terhadap orang yang senantiasa berakhlak baik, dalam Surah an-Nahl ayat 97, sebagai berikut.

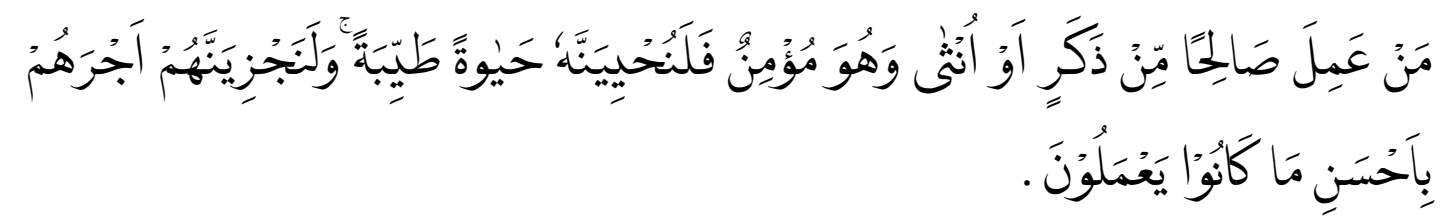

Terjemahannya:

"Barangsiapa yang mengerjakan amal saleh, baik laki-laki maupun perempuan dalam keadaan beriman, maka sesungguhnya akan Kami berikan kepadanya kehidupan yang baik dan sesungguhnya akan Kami beri balasan kepada mereka dengan pahala yang lebih baik dari apa yang telah mereka kerjakan.” (QS. an-Nahl [16]: 97).

Selaras dengan penjelasan dan pemaparan di atas, diutarakan pula oleh informan Bapak Haji Bakri yang merupakan tokoh adat di Kampung Kukup, yang mengatakan sebagai berikut.

"Sebenarnya manusia itu maunya yang baik-baik saja siapapun itu dan diamanpun termasuk orang Bugis ini. Nilai yang nantinya didapatkan atau dirasakan ini memang sesuai dengan ajaran Islam karena Islam memang sebagai Agama yang ada pengaturannya dan penuh dengan kebaikan makanya persis juga dengan Ininnawa”.

Orang yang selalu menerapkan nilai Akhlakul Karimah, akan selalu senantiasa memperoleh sebuah kehidupan yang baik, mendapatkan pahala yang berlipat ganda dan di akhirat nanti akan dimasukkan ke dalam surganya Allah SWT. Dengan demikian, orang yang berakhlak mulia akan mendapatkan keberuntungan hidup di dunia dan di akhirat. Hal ini didukung oleh sebuah Kenyataan sosial yang membuktikan bahwa orang yang berakhlak baik akan disukai oleh masyarakat, kesulitan atau 
kekurangannya akan dibantu untuk diselesaikan, walau mereka tidak mengharapkannya. Peluang, kepercayaan dan kesempatan datang silih berganti kepadanya, karena akhlak yang baik diterapakan dalam kehidupan dan dirasakan oleh orang lain.

\section{KESIMPULAN}

Tradisi Ininnawa merupakan sebuah system yang memiliki manfaat yang nantinya akan dirasakan bagi generasi suku Bugis di Kampung Kukup dalam memelihara dan memperbaiki serta memotivasi pengembangan budaya, juga menguntungkan bagi masyarakat suku Bugis sendiri dimana merupakan kebutuhan untuk dapat menjaga generasinya agar tetap berada dalam lingkaran kebaikan serta mendapatkan sebuah jaminan tentang bagaiamana menghadapi serta menanggulangi tantangan zaman, dimana tujuan Ininnawa adalah adanya harapan bagi generasi Bugis yang ada di Kampung Kukup mampu menyesuaikan diri dengan lingkungan serta menyesuaikan lingkungan tersebut dengan kebutuhannya. Ininnawa merupakan sebuah pembelajaran dalam rangka pembentukan kecakapan secara intelektual serta mengasah emosional untuk membantu bagi generasinya tentang suatu prinsip yang nanti harus di pegang teguh pada masa kedewasaan yaitu sebuah "Kesungguhan" dan "Rasa Malu", sehingga sangat ditanamkan di dalam diri mereka tentang semangat untuk selalu berhasil. Pelaksanaan tradisi ini dapat menjalankan sebuah kegiatan pelestarian kebudayaan dan diharapkan dapat berlangsung dari masa ke masa terarah dan terpadu secara dinamis dimana di dalamnya merupakan cara hidup suatu masyarakat yang merupakan warisan secara turun temurun dari leluhurnya, yang mengandung filosofi tentang cara berfikir, merasa serta percaya berkaitan dengan tingkah laku dalam bermasyarakat yang terkandung dalam falsafah Sipakatau (sifat yang tidak saling membeda-bedakan), Sipakainge (Sifat dimana kita saling mengingatkan), Sipakalebbi (Sifat saling menghargai sesama manusia), yang merupakan pembelajaran bagi generasi muda Bugis di Kampung Kukup dalam menghadapi berbagai permasalahan yang nantinya bakal dihadapi dalam kehidupannya. Ininnawa yang dilakukan di Kampung Kukup adalah dalam rangka mempertahankan nilai-nilai budaya tradisional masyarakat Bugis dalam rangka mempersiapkan diri menyikapi situasi dan kondisi kehidupan yang selalu berubah. Tradisi Ininnawa ini merupakan sebuah kebiasaan-kebiasaan baik yang diturunkan oleh leluhur yang berkaitan dengan kepribadian dan sikap social dalam kehidupan bermasyarakat. Tradisi ini mampu menyelaraskan tugas pokok dan fungsinya untuk mengikuti zaman serta dapat ikut menjadi sebuah kebaikan dimanapun dan kapanpun tradisi ini diterapkan. Tradisi ini selaras dengan ajaran Islam yang mengajarkan tentang akhlak yang baik sesuai dengan tuntutan Al-Qur'an dan Hadits.

Saran yang dapat disampaikan adalah: perlu adanya dukungan dari seluruh masyarakat Bugis yang ada di Kota Jayapura agar dapat mengembangkan tradisi Ininnawa agar tradisi tersebut dapat terpelihara serta mampu meningkatkan adab kebiasaan yang baik yang diturunkan oleh leluhur generasi Bugis. 


\section{REFERENSI}

\section{Buku}

Ahmad (2005). Amber dan Komin. Studi Perubahan Ekonomi di Papua. Yogyakarta: Bigraf Publishing, Yayasan Adhikarya IKAPI, dan Ford Foundation.

Arifin. H.M.. (2008). Ilmu pendidikan Islam. Jakarta: PT. Bumi Aksara.

Geertz Clifford. (1992). Tafsir Kebudayaan. Yogyakarta: Kanisius.

Mujib, Abdul. (2006). Ilmu Pendidikan Islam. Jakarta: Kencana Prenada Media.

Nata, Abudin. (200o). Akhlak Tasawuf. Cet. III. Jakarta: Raja Grafindo.

Ranjabar, Jacobus. (2006). Sistem Sosial Budaya Indonesia: Suatu Pengatar. Bandung: Ghalia Indonesia.

Roucek, S. Joseph., \& Warren, L. Roland. (1984). Pengantar Sosiologi. Bandung: Bina Aksara.

Sedyawati, Edi. (2006). Budaya Indonesia: Kajian Arkeologi, Seni, dan Sejarah. Jakarta: Raja Grafindo Persada.

\section{Jurnal dan lainnya}

Nawir, M.S., et.al. (2020). Famajal (Potret Tradisi Pengakuan Kekerabatan Masyarakat kampung Lilinta Distrik Misool Barat Kabupaten Raja Ampat, Melalui Ritual Keagamaan). Jurnal Sosiologi Agama: Jurnal Ilmiah Sosiologi Agama dan Perubahan Sosial. 14(2), 159-178. http://doi.org/10.14421/jsa.2020.142-02

Nahak, Hildigardis M. I. (2019). Upaya Melestarikan Budaya Indonesia di Era Globalisasi. Jurnal Sosiologi Nusantara. 5(1). $65-76$. https://doi.org/10.33369/jsn.5.1.65-76.

Norianda, Nindiya., et.al. (2021). Internalisasi Nilai dan Karakter Melalui Budaya Sekolah (Suatu Budaya Sekolah Jumat Berkah). WASKITA: Jurnal Pendidikan Nilai dan Pembangunan Karakter. 5(1), 45-57. https://doi.org/10.21776/ub.waskita.2021.005.01.4

Priyatna, Muhammad. (2016). Pendidikan Karakter Berbasis Kearifan Lokal. Edukasi Islami: Jurnal Pendidikan Islam. 5(10), 1311-1336. http://dx.doi.org/10.30868/ei.v5i10.6

Salim, Arhanudin., et.al. (2018). Pendidikan Karakter Dalam Masyarakat Bugis. Ijtimaiyya: Jurnal Pengembangan Masyarakat Islam. 11(1), 41-62. https://doi.org/10.24042/ijpmi.v11i1.3415

Suhra, Sarifa. (2019). Nilai-Nilai Pendidikan Karakter Dalam Budaya Masyarakat Bugis Bone. Jurnal Darussalam: Jurnal Pendidikan, Komunikasi dan Pemikiran Hukum Islam, (S1), 11(1), 222-241. https://doi.org/10.30739/darussalam.v11i1.459

JDIH BPK RI. Undang-Undang Nomor 20 Tahun 2003 tentang Sistem Pendidikan Nasional. Accessed 9 September 2021. Retrieved from https://peraturan.bpk.go.id/Home/Details/43920/uu-no-2O-tahun2003 
Yusuf, Muhamad., et.al. (2021). Membangun Dunia Pendidikan Islam Di Tengah Keterbatasan (Potret Pondok Pesantren Di Kota Jayapura). Edukasi Islami: Jurnal Pendidikan Islam. 1O(1), 73-98. https://doi.org/10.30868/ei.v10io1.1035

Yusuf, Muhamad., et.al. (2021). Persepsi Hukum Adat larvul Ngabal Pada Masyarakat Kei Perantauan Di Kota Jayapura. POROS ONIM: Jurnal Sosial Keagamaan. 2(1). 2O-36. https://doi.org/10.53491/porosonim.v2i1.47

Yusuf, Muhamad., et.al. (2021). Komersialisasi Lahan Pertanian Di Koya Barat dan Koya Timur, Kota Jayapura. AGRISEP: Jurnal Kajian Masalah Ekonomi Pertanian dan Agribisnis. 2O(1), 157-178. https://doi.org/10.31186/jagrisep.20.1.157-178

Yusuf, M. Y., et.al. (2020). The Rise Of Children Dropping Out Of School In Raja Ampat. AL-ISHLAH: Jurnal Pendidikan, 12(2), 270-287. https://doi.org/10.35445/alishlah.v12.i2.225

\section{Interview}

Wawancara Dengan Bapak Muh. Nur selaku ketua RT.02. Pada 22 Agustus 2019 Di Kampung Kukup Koya Koso.

Wawancara Dengan Bapak H. Bakri. Pada 22 Agustus 2019 Di Kampung Kukup Koya Koso.

Wawancara Dengan Bapak H. Tahir. Pada 27 Agustus 2019. Di Kampung Kukup Koya Koso. 